\title{
Statistical and econometric analysis of the correlation between financial transactions and real economy
}

\author{
Simona-Andreea APOSTU \\ The Bucharest University of Economic Studies, Bucharest, Romania \\ simona.apostu@csie.ase.ro
}

\begin{abstract}
The economic activity generates two types of flows: flows of goods and services and cash flows. These two types of flows generate two types of circuits in the economy, flows of goods and services generate the circuit corresponding to real economy and monetary flows (incomes and expenditures) generate the monetary - financial circuit. The monetary circuit is fundamentally determined by the level and structure of real economy. Comparing production revenue used for consumption with the amount of products and services produced and purchased, an average pricing is obtained. Unless the condition that the revenues generated in the economy are equal to production, it will lead to rising prices, i.e., inflation. Therefore, an adequate correlation between financial flows and real economy must be ensured. From this perspective, were analysed countries from European Union over time, using panel analysis.
\end{abstract}

Keywords: real economy, financial transactions, panel data, GDP, unemployment rate, labour productivity, balance of payments.

\section{Introduction}

Real economy and financial flows involve complex processes and phenomena, highlighting an economic dependence being possible if we consider transversal changes and changes over time.

Territorial comparisons have peculiarities over time. For comparisons over time, we compare an indicator for a given community or entity over a period called the current period, denoted by 1 , with the same indicator level for the same collectivity in a period taken as the basis of comparison, denoted by 0 . The comparison can be written: $\mathrm{x}_{1}-\mathrm{x}_{0}$ or $\frac{x_{1}}{x_{0}}$, the indicator is common, the collectivity is the same, but the time is different.

In the case of territorial comparisons, the level of an indicator is compared over a period of time recorded in a territory A, with the level of the same indicator at the same time for another territory, $\mathrm{B}$.

In the territorial case, the comparison can be written: $\mathrm{x}_{\mathrm{A}}-\mathrm{x}_{\mathrm{B}}$ or $\frac{x_{A}}{x_{B}}$ and we have the same indicator, the same time period, but the community, the territory, is different.

To highlight the dependence territorial and over time, it is proposed to use the panel data analysis.

The real economy is characterized by the goods and services market, labour market and external balance, and the indicators that illustrate these are: GDP (real), Labour Productivity, Exports, Imports and Unemployment Rate.

Financial flows are represented by financial balance and financial transactions.

The analysis is aimed to outline a picture of the current situation in EU, regarding real economy and financial flows. So, using panel data, was established the influence of the variables that describe the real economy on financial balance. 


\section{Literature review}

Gheorghe Manolescu said about flows that: "Real flow measurement is based on monetary evaluation, but flows can only be generated by a prior accumulation of goods, services or currency to each economic agent, and each flow changes the volume of economic goods. The stock of assets held by an enterprise at one time constitutes the enterprise's business capital. A stock only has significance at one point, while a flow can only be measured over a given period. Relations between flows and stocks are the foundations of financial mechanisms"(Manolescu, 1995).

The nominal income objective is a monetary policy rule that sets interest rates in response to nominal GDP growth deviations. In the United States, simulations of nominal income performance were performed using quarterly data. The results suggested that the nominal income target is well established in relation to the inflation target and Taylor rules, highlighting a dependence between national income and inflation (McCallum and Taylor, 1999).

Webber (2001) analysed the finance and real economy in Asia and the implications of the financial crisis. The paper assessed the implications of the Asian financial crisis for theories on developing a global economy, identifying the dependence between financial flows and real economy. The financial crisis reflects the real conditions, although the crisis has been driven by financial considerations and reflects the way the world financial system operates.

Arestis and Sawyer (2002) argued that monetary policy affects the real economy, involving the manipulation of the central bank's interest rate. The objective of monetary policy is the rate of inflation, but it can also include the level of economic activity. After analysing the European Union, the United States and the United Kingdom, the results show that changes in the interest rate influence inflation to a small extent and that monetary policy can have long-term effects on real magnitudes. The results of the study differ from the actual theory of current monetary policy.

Calderon and Liu (2003) studied the link between financial development and economic growth using the Geweke decomposition test on a sample of 109 developing and industrial countries between 1960 and 1994. The study concluded that financial development leads to economic growth, existing a causal relationship Granger. Economic growth is influenced by deepening, rapid capital accumulation, and, increasing productivity.

Green and Murinde (2003) studied financial flows, both theoretically and empirically, and established that there is a dependence between the flow of funds, interest rates and asset prices and the revenue and expenditure of an economy. The paper examines the financial flows in the context of developing countries and establishes that there is a relationship between the development of the financial sector and the real economy, thus identifying the effective policies of the financial sector in developing countries.

Obtaining economic goods involves movements of goods, works and services, and money movements. All these movements are called economic flows because they are related to the unfolding of economic life. Movements in goods, works and services are real flows. Real flows involve monetary flows. (Banc, 2006)

Imbs (2006) studies the real effects of financial integration, showing how GDP fluctuations correlate with financial integration. Financial flows influence the correlation 
between consumption fluctuations and GDP. Although theory suggests a negative relationship, Imbs establishes a positive correlation between financial integration and GDP.

Popescu and Nica (2006) compared the real dynamics of the Romanian economy with the nominal one. Real economy represents the flows of goods and services driven by their production, circulation and use in an institutional framework, and the nominal economy represents the financial flows that accompany the real flows of goods and services within the economic circuit. There is a dependence between the real and the nominal economy, and the characteristics of this link are influenced by the state of the economic system at that period. The causes that influence this dependence are: the production omitted by the official statistical system, output that comes out of the official estimates because the economic agents evade tax obligations, the production of prohibited legal goods, the redistribution of income through unauthorized channels, investment processes and officially uncontributed production.

Claessens, Tong and Wei (2012) analysed the real economy in the context of the financial crisis, using the accounting data for 7722 non-financial firms from 42 countries for the 2007-2009 period. The analysis aimed to isolate and compare the effects of changes in the economic cycle, international trade and external financing conditions, taking into account companies' profits, sales and investments, using both sectoral benchmarks and business specific sensitivities before the crisis. The result of the study was that the negative impact of the crisis was greater on firms that are more financially sensitive, especially in countries open to trade.

Rey (2015) analysed global financial cycle and monetary policy independence, the global financial cycle representing capital flows, asset prices and credit growth. A VAR analysis suggested that monetary policy is one of the determinants of the global financial cycle, it affects the leverage of global banks, capital flows and credit growth in the international financial system. Independent monetary policies are possible if the capital account is managed well.

\section{Methodology}

Real economy and financial flows involve complex processes and phenomena, highlighting an economic dependence being possible if we consider transversal changes and changes over time.

Territorial comparisons have peculiarities over time. For comparisons over time, we compare an indicator for a given community or entity over a period called the current period, denoted by 1 , with the same indicator level for the same collectivity in a period taken as basis of comparison, denoted by 0 . The comparison can be written: $\mathrm{x}_{1}-\mathrm{x}_{0}$ or $\frac{x_{1}}{x_{0}}$, the indicator is common, the collectivity is the same, but the time is different.

In the case of territorial comparisons, the level of an indicator is compared over a period of time recorded in a territory $A$, with the level of the same indicator at the same time for another territory, $\mathrm{B}$.

In the territorial case, the comparison can be written: $\mathrm{x}_{\mathrm{A}}-\mathrm{x}_{\mathrm{B}}$ or $\frac{x_{A}}{x_{B}}$ and we have the same indicator, the same time period, but the community, the territory, is different. 
To highlight the dependence territorial and over time, it is proposed to use the panel data analysis.

Models for panel data consists of regression equations, in which both time series and cross-sectional data are used. In the analysis of socio-economic phenomena and processes at regional level, both macroeconomic and microeconomic, panel data are recommended (Manole, Tache et al., 2014).

Panel analysis has been used in social sciences in many contexts. Over time, the features and particularities of the phenomena are not stable, therefore, panel analysis is recommended instead cross-section (Kessler and Greenberg, 1981).

Judson and Owen (1999) used panel data analysis to establish the dependence between the saving rate and revenue growth.

In Germany, has been studied the wage effects of educational mismatch using panel data between 1984-1998. The results confirmed the theory in the literature, the estimated differences between appropriately trained and inadequately trained workers tend towards 0 if unacceptable heterogeneity is controlled (Bauer, 2002).

Brueckner (2003) used panel data to decide on strategic interaction between local authorities.

Carneiro, Hansen and Heckman (2003) applyed panel models in microeconomics, for education, determining the intrinsic uncertainty are facing the factors when they make decisions about enrolling in school.

Carstensen and Toubal (2004) studied the determinants of foreign direct investment (FDI) in Central and Eastern European countries using dynamic data methods. The empirical model with panel data analysis shows that potential market, reduced labour costs, skilled workforce and relative facilities are significant factors of influence. The level and method of privatization and country risk significantly influenced the determination of FDI flows in CEE countries and determined the country's attractiveness to foreign investors.

Lee analysed energy consumption and GDP in 18 developing countries using panel data for the 1975-2001 period. The results indicated that long-term and short-term causality is influenced by the share of energy consumption in GDP. The conclusion of the study is that energy conservation can influence negatively the economic growth in developing countries (Lee, 2005).

Hsiao and Hsiao (2006) used panel analysis to highlight the Granger causality between GDP, exports and FDI (foreign direct investment). The study is based on data for China, Korea, Taiwan, Hong Kong, Singapore, Malaysia, the Philippines and Thailand and Southeast Asia for the 1986-2004 period. The conclusion of the study is that each country has different causal relationships and does not provide general rules. Between FDI and GDP there is a direct link, and a reverse link between exports and FDI and between exports and GDP.

Elhorst (2008) established the link between labour participation rates, gender and age, using annual data (1983-1997) from 154 regions (10 States from EU).

At G7 level, Fountas and Karanasos analysed inflation and growth, using monthly records for the 1957-2000 period and unrated GARCH models. The Group of 7 (G7) is a group consisting of Canada, France, Germany, Italy, Japan, the United Kingdom and the United States. The results of the study revealed that inflation positively influences inflation 
uncertainty, and the uncertainty of the increase in production positively influences the production growth rate. Inflation uncertainty influences inflation and production. The conclusion of the study is that inflation uncertainty does not negatively influence economic growth, and economic uncertainty does not necessarily increase inflation (Fountas and Karanasos, 2007).

Hwang and Wu analysed the link between China's inflation and growth. Using official regional data for the gross regional product, the consumer price index from 1986 to 2006, the authors are investigating the non-linear effects of inflation on Chinese economic growth. The results of the study indicated that the effect of the inflation threshold is significant and robust in China. At thresholds above $2.50 \%$, an increase of 1 percentage point in the inflation rate hinders economic growth by $0.61 \%$, at less than $2.5 \%$ thresholds, the 1 percentage point increase in inflation rate stimulates an increase of $0.53 \%$. In conclusion, in China, over 20 years, high inflation had a negative influence on economic growth, while moderate inflation favored economic growth. The study's recommendation is that a moderate inflation rate should be maintained for long-term growth (Hwang and $\mathrm{Wu}, 2011$ ).

Otoiu (2014) analysed migration at EU's level between 2000 and 2007, using panel data, and concluded that most of the models and variables used in migration analysis are valid for international migration.

Dimian, Begu et al. (2017) used panel data to investigate some of the main drivers of high unemployment rates in the countries of EU. They concluded that unemployment rates of young and low educated workers influence the economic growth variations, and the unemployment rate of older workers is better adjusted.

A longitudinal study is one that collects data from subjects of the same sample over time. These advantages have been increasingly recognized and appreciated in recent years, resulting an increased number of longitudinal studies. This increase in interest occurred in government, academia and the private sector (Lynn, 2009).

A data table is a set of cross-section data $Y_{i t}$, where $i=1, \ldots, n$ is the section component and $t=1, \ldots, \mathrm{T}$ is the time component). $\mathrm{Y}_{\text {it }}$ is obtained by registering the variables characteristic of a group of $\mathrm{n}$ countries, over time, within a defined time period, $\mathrm{T}$ (Baltagi, 2005).

In the panel analysis, for estimating the variation of a resultant variable depending on the determinants is considered the following model:

$\mathrm{y}_{\mathrm{it}}=\mathrm{b}_{0 \mathrm{it}}+\mathrm{b}_{1 \mathrm{it}} \mathrm{x}_{1 \mathrm{it}}+\ldots+\mathrm{b}_{\mathrm{kit}} \mathrm{X}_{\mathrm{kit}}+\mathrm{w}_{\mathrm{it}}$ $1, \ldots, \mathrm{n}$ and $\mathrm{t}=1, \ldots, \mathrm{T}$.

(1), with i =

$Y_{\text {it }}$ are the values for the depending variable and $x_{k i t}$ are the values for the independent variables, $X_{k}$. The value $b_{0 i t}$ is a constant, and $b_{k i t}$ represent the estimates of the coefficients of the variables $X_{k}$, recorded for a country at the time $t$, and $w_{i t}$ is the estimated error (Sevestre, 2005).

If the $b_{\text {kit }}$ coefficients are equal, the variables $X_{k}$ has a constant influence on the dependent variable over time, the proposed model is homogeneous and if the $b_{\text {kit }}$ coefficients are not equal, then the model is heterogeneous.

The number of coefficients $(\mathrm{nT}(\mathrm{K}+1))$ is bigger than the number of observations (nT), so the model can not be estimated based on traditional methods, and it is necessary using different coefficients. Can be defined four canonical models: fixed effects (individual 
and transversal), composite errors (random effects), compound coefficients and random coefficients (Jaba, Robu et al., 2013).

The study considers the model with fixed effects. The model with fixed effects considers that the independent variables $\left(\mathrm{X}_{\mathrm{k}}\right)$ is influencing the depending variable $\left(\mathrm{Y}_{\mathrm{k}}\right)$ identical for all countries, no matter the time period considered $\left(b_{k i t}=b_{k}\right)$, and the constant $\left(b_{0 i t}\right)$ may be decomposed as follows: $b_{0 i t}=b_{0}+a_{i}+d_{t}$, where $b_{0 i t}$ represents the constant of the regression model, $b_{0}-a$ constant, $a_{i}$ are the unobservable differences between countries, i.e,. the fixed individual effects or the country specific characteristics, and $d_{t}$, the differences existing in a country across time, i.e., the fixed temporal effects or the existence of a specificity in a country over time.

For estimating the impact of GDP, unemployment rate, exports, imports and labour productivity on financial transactions in European countries each year for the period 20072016, the following models with fixed effects is proposed:

$\mathrm{FB}_{\text {it }}=\mathrm{b}_{0}+\mathrm{a}_{\mathrm{i}}+\mathrm{d}_{\mathrm{t}}+\mathrm{b}_{1 \mathrm{GDPit}}+\mathrm{b}_{2 \text { URit }}+\mathrm{b}_{3 \text { Expit }}+\mathrm{b}_{4 \text { Impit }}+\mathrm{b}_{5 \mathrm{LPit}}+\mathrm{w}_{\text {it }}$

where the dependent variable is the financial balance and

$\mathrm{FT}_{\text {it }}=\mathrm{b}_{0}+\mathrm{a}_{\mathrm{i}}+\mathrm{d}_{\mathrm{t}}+\mathrm{b}_{1 \mathrm{GDPit}}+\mathrm{b}_{2 \mathrm{URit}}+\mathrm{b}_{3 \text { Expit }}+\mathrm{b}_{4 \text { Impit }}+\mathrm{b}_{5 \mathrm{LPit}}+\mathrm{w}_{\mathrm{it}}$

where the dependent variable is the financial transactions.

Using data for the EU's countries, the model aims to evaluate the dependence between the factors related to the real economy (GDP, labour productivity, export, import and unemployment rate) with those relating to financial flows (financial balance and financial transactions).

The estimation of the model equations (determination of the parameter estimators) was made on the basis of the values recorded for the eight indicators in the 28 countries of the EU during 2007-2016. Therefore, two indices are used: $\mathrm{t}=$ time generic index, $\mathrm{t}=2007$, $2008, \ldots, K, \ldots, 2016$ and $\mathrm{i}=$ generic index for the region, $\mathrm{i}=1,2, \ldots, \mathrm{K}, \ldots ., 28$.

The data on these variables were collected for EU for the period 2007-2016 using Eurostat online database. To obtain the results of the research, the collected data were analysed with the statistical software R.

\section{Results and discussions}

In order to establish links between financial flows and real economy, an analysis was undertaken in several countries. Because the production structure is strongly influenced by the area, for the comparison to be relevant, were chosen countries from the same area, respectively the EU.

In order to characterize the real economy, we considered the goods and services market, the labour market and external balance, and the considered indicators are: GDP (real), labour productivity, export, import and unemployment rate. Financial flows are represented by financial balance and financial transactions.

PIB is the main economic indicator that points to economic growth. It includes the effect of all direct factors of production: fixed capital, labour force and circulating assets. Regarding to the workforce, labour productivity and employment rate must be big, and unemployment rate must be small. Between GDP and labour productivity is a direct dependence. In economic theory, the dependence between unemployment and GDP is inverse, also called Okun's law. In the recession period, GDP is decreasing and 
unemployment is rising, and GDP is rising and unemployment is decreasing during the expansion period (Anghelache, Mitrut, et al., 2013).

Financial Balance collects and presents the international statistics of a country, its components being current transactions and capital transfers (financial transactions).

Milton Friedman studied monetary circulation in the United States for a century and found that between GDP and the money supply is a direct dependence regardless of the conjuncture, this being a condition of monetary equilibrium.

For comparability, indicators are calculated according to the same calculation methodology, expressed in percentage or value, in the same currency unit, i.e., Euro.

Table 1. The variables

\begin{tabular}{|l|l|l|}
\hline Symbol & Variable description & Calculation method \\
\hline GDP & Gross Domestic Product & Real GDP - Percentage change on previous year (volume) \\
\hline LP & Labour Productivity & Compensation per employee - EURO \\
\hline Exp & Exports of goods and services & Chain linked volumes (2010) - million euro \\
\hline Imp & $\begin{array}{l}\text { Imports of goods and } \\
\text { services }\end{array}$ & Chain linked volumes (2010) - million euro \\
\hline UR & Unemployment Rate & Unemployment rate - Percentage of active population \\
\hline FB & Financial Balance Sheets & Total financial assets/liabilities - Million Euro \\
\hline FT & Financial Transactions & $\begin{array}{l}\text { Net acquisition of financial assets/Net incurrence of liabilities - } \\
\text { Million euro }\end{array}$ \\
\hline
\end{tabular}

Source: Author's own research.

Because exports and imports are strong correlated, only exports were remaining in the analysis.

Table 2. Matrix of correlations between variables

\begin{tabular}{|l|l|l|l|l|l|l|}
\hline & FB & Exports & FT & RealGDP & Imports & Lproductiv \\
\hline FB & $\mathbf{1}$ & 0.88841030 & 0.4856858 & 0.04611506 & 0.873258653 & 0.45720750 \\
\hline Exports & 0.88841030 & $\mathbf{1}$ & 0.3491532 & 0.015091722 & 0.991808541 & 0.43513779 \\
\hline FT & 0.48568582 & 0.34915323 & $\mathbf{1}$ & 0.158077319 & 0.321785141 & 0.32676125 \\
\hline RealGDP & 0.04611506 & 0.01509172 & 0.1580773 & $\mathbf{1}$ & 0.003802712 & -0.0220075 \\
\hline Imports & 0.87325865 & 0.99180854 & 0.3217851 & 0.003802712 & $\mathbf{1}$ & \\
\hline Lproductiv & 0.45720750 & 0.43513779 & 0.3267612 & -0.0220075 & 0.440684761 & $\mathbf{1}$ \\
\hline
\end{tabular}

Source: Author's own research.

Table 3. Statistics on Fixed Asset Model Assessment

\begin{tabular}{|l|l|}
\hline \multicolumn{2}{|c|}{ Regression model statistics } \\
\hline Total Sum of Squares & $5.1971 \mathrm{e}+13$ \\
\hline Residual Sum of Squares & $3.2491 \mathrm{e}+13$ \\
\hline R-Squared & 0.37482 \\
\hline Adj. R-Squared & 0.2464 \\
\hline
\end{tabular}




\begin{tabular}{|l|l|}
\hline F-statistic & 27.7286 \\
\hline Degrees of freedom & $4 / 185$ \\
\hline p-value & $2.22 \mathrm{e}-16$ \\
\hline
\end{tabular}

Source: Author's own research.

All these values are lower than the 5\% threshold, so we can accept that the model parameters are significantly different from zero. Coefficient of determination (R-squared) is 0.3748 , which shows that $37.48 \%$ of the financial balance changes is due to the variables considered - labour productivity, export, GDP and unemployment rate. Adjusted R-squared coefficient is also used to measure the regression equation, but it is smaller, 0.25 . The significance level of test $F$ is less than the threshold we are testing, usually 0.05 , so we reject the null hypothesis that all regression coefficients are zero. Therefore, it can be said that there is a statistically significant relationship between the dependent variable and the independent variables.

Table 4. Estimates of the regression parameters

\begin{tabular}{|l|l|l|l|l|}
\hline Variables & Estimate & Std. Error & t-value & $\operatorname{Pr}(>|\mathbf{t}|)$ \\
\hline RealGDP & $2.3060 \mathrm{e}+04$ & $1.1091 \mathrm{e}+04$ & 2.0792 & $0.03898^{*}$ \\
\hline Lproductivity & $1.1619 \mathrm{e}+02$ & $2.4476 \mathrm{e}+01$ & 4.7473 & $4.117 \mathrm{e}-06^{* * *}$ \\
\hline Exports & $7.0018 \mathrm{e}+00$ & $9.2966 \mathrm{e}-01$ & 7.5316 & $2.145 \mathrm{e}-12^{* * *}$ \\
\hline UR & $3.2037 \mathrm{e}+04$ & $1.5004 \mathrm{e}+04$ & 2.1352 & $0.03406^{*}$ \\
\hline
\end{tabular}

Source: Author's own research.

The regression equation between financial balance and the other variables can be written as follows:

$\mathrm{FB}=23060 *$ RealGDP $+116,19 *$ Lproductivity $+7.0018 *$ Exports $+32037 *$ UR

Therefore, increases in real GDP, exports, unemployment rates and labour productivity lead to increases in financial balance. One unit growth of GDP increases the financial balance by 23060 million euro, the increase of labour productivity with one unit determines an increase of the financial balance by 116.19 million euro, one unit growth of export increases the financial balance by 7.0018 million euro and when the unemployment rate increases by one unit, the financial balance increases by 32037 million euro.

\section{Conclusion}

Using the panel data regression for real economy and financial transactions, it was established that for EU countries there were strong correlations between all analysed variables and a regression equation between financial balance and the independent variables was established.

Economically, the model highlights the dependence between economic and social variables related to the real economy of a country and the financial flows, represented by the financial balance. Therefore, it can be said that the model creates a convincing picture of the influences between the important indicators for the real economy of a country and the financial flows. Therefore, increases in real GDP, exports, unemployment rates and labour productivity lead to increases in financial balance. One unit growth of GDP increases the financial balance by 23060 million euro, the increase of labour productivity with one unit 
determines an increase of the financial balance by 116.19 million euro, one unit growth of export increases the financial balance by 7.0018 million euro and when the unemployment rate increases by one unit, the financial balance increases by 32037 million euro.

Subsequent developments in the study should enlarge the sample, considering the global economy and should also include other socio-economic factors.

PICBE $\mid 78$

\section{References}

Anghelache, C., Mitrut, C., Voineagu,V. (2013). Macroeconomic statistics. Bucharest: Economic Press.

Arestis, P., Sawyer, M.C. (2002). Can Monetary Policy Affect the Real Economy?. Levy Economics Institute. Working Paper 335, 1-13.

Baltagi, B. (2005). Econometric Analysis of Panel Data (3rd Edition). West Sussex: John Wiley \& Sons.

Banc, P. (2006). Some Aspects Relating to Flows and Financial Cycles. Oeconomica, 8(2), 1317.

Bauer, T.K. (2002). Educational mismatch and wages: a panel analysis. Economics of Education Review, 21(3), 221-229.

Brueckner, J.K. (2003). Strategic interaction among local governments: an overview of empirical studies. International Regional Science Review, 26(2), 175-188.

Calderón, C., Liu, L. (2003). The direction of causality between financial development and economic growth. Journal of Development Economics, 72(1), 321-334.

Carneiro, P., Hansen, K. T., Heckman, J. J. (2003). Estimating distributions of treatment effects with an application to the returns to schooling and measurement of the effects of uncertainty on college choice. International Economic Review, 44(2), 361422.

Carstensen, K., Toubal, F. (2004). Foreign direct investment in Central and Eastern European countries: a dynamic panel analysis. Journal of Comparative Economics, 32(1), 3-22.

Claessens, S., Tong, H., Wei, S.J. (2012). From the financial crisis to the real economy: Using firm-level data to identify transmission channels. Journal of International Economics, 88(2), 375-387.

Dimian, G., Begu, L.S., Jablonsky, J. (2017). Unemployment and labour market mismatch in the European Union Countries. Zbornik radova Ekonomskog fakulteta u Rijeci: časopis za ekonomsku teoriju i praksu, 35(1), 13-44.

Elhorst, J.P. (2008). A spatiotemporal analysis of aggregate labour force behaviour by sex and age across the European Union, Journal of Geographical Systems, 10(2), 167190.

Fountas, S., Karanasos, M. (2007). Inflation, output growth, and nominal and real uncertainty: Empirical evidence for the G7. Journal of International Money and Finance, 26(2), 229-250.

Green, C.J., Murinde, V. (2003). Flow of funds: implications for research on financial sector development and the real economy. International Development, 15(8), 1015-1036. 
Hsiao F.S.T., Hsiao, M.C.W. (2006). FDI, exports, and GDP in East and Southeast Asia-Panel data versus time-series causality analyses. Journal of Asian Economics, 17(6), 10821106.

Hwang, J.T., Wu, M.J. (2011). Inflation and Economic Growth in China: An Empirical Analysis. China \& World Economy, 19(5), 67-84.

Imbs, J. (2006). The real effects of financial integration. Journal of International Economics, 68(2), 296-324.

Jaba, E., Robu, I.B., Balan, C.B., Robu, M.A. (2013), The Panel Data Analysis of Fraud Risk in Financial Auditing. Audit Financiar, No. 05, 25-36.

Judson, R. A., Owen, A. L. (1999). Estimating dynamic panel data models: a guide for macroeconomists. Economics letters, 65(1), 9-15.

Kessler, R.C., Greenberg, D.F. (1981). Linear Panel Analysis. Models of Quantitative Change. New York: Academic Press.

Lee, C.C. (2005). Energy consumption and GDP in developing countries: A cointegrated panel analysis. Energy Economics, 27(3), 415-427.

Lynn, Peter. (2009). Methodology of Longitudinal Surveys. 1st Edition. Chichester: Wiley.

Manole, S.D., Tache, A., Tache. M. (2014). Study of regional development through models with panel data. The Romanian Journal of Statistics, Supliment 8, 1-15.

Manolescu, G. (1995). Financial Management. Bucharest: Economic Press.

McCallum, B.T., Nelson, E. (1999). Nominal income targeting in an open-economy optimizing model. Journal of Monetary Economics, 43(3), 553-578.

Otoiu, A. (2014). Getting your Migration Analysis Together by Integrating Internal and International Migration. Procedia - Social and Behavioral Sciences, 149, 685-690.

Popescu, G., Nica, E. (2006). The real - nominal interaction in the dynamics of the Romanian economy. AGER Magazine, 496, 108-111.

Rey, H. (2015). Dilemma not Trilemma: The global Financial Cycle and Monetary Policy Independence. NBER Working, Paper No. 21162.

Sevestre, P. (2002). Économetrie des données de panel. Paris: Dunod.

Webber, M. (2001). Finance and the real economy: theoretical implications of the financial crisis in Asia. Geoforum, 32(1), 1-13. 